九州大学学術情報リポジトリ

Kyushu University Institutional Repository

\title{
Weevils of the genus Adorytomus Voss (Coleoptera, Curculionidae) from Vietnam
}

Kojima, Hiroaki

Laboratory of Entomology, Tokyo University of Agriculture

Truong, Xuan, Lam

Institute of Ecology \& Biological Resources, Vietnamese Academy of Science \& Technology

https://doi.org/10.5109/25393

出版情報: ESAKIA. 52，pp.35-39，2012-03-27. Entomological Laboratory，Faculty of Agriculture， Kyushu University

バージョン :

権利関係 : 


\title{
Weevils of the Genus Adorytomus Voss (Coleoptera, Curculionidae) from Vietnam
}

\author{
Hiroaki KoJima $^{1)}$ and Xuan Lam Truong ${ }^{2)}$ \\ 1) Laboratory of Entomology, Tokyo University of Agriculture, 1737 Funako, Atsugi, Kanagawa, \\ 243-0034 Japan \\ 2) Institute of Ecology \& Biological Resources, Vietnamese Academy of Science \& Technology, \\ 18 Hoang Quoc Viet Road, Cau Giay, Ha Noi, Vietnam
}

\begin{abstract}
Adorytomus tadauchii sp. nov. and A. yukikoae sp. nov. are described from Tam Dao, N. Vietnam as the first record of the genus from the country. Weevils were captured on and seriously infesting leaves of Eurya nitida of the camellia family, Theaceae.
\end{abstract}

Key words: taxonomy, Coleoptera, Curculionidae, Adorytomus, Vietnam, new species.

The plant family Theaecae, especially represented by the genus Camellia, has great economical importance in East Asia, where the distributional center of this family is located (Min \& Bartholomew, 2007). Weevil fauna of this plant family is not yet well defined in spite of their potential likelihood of being pests.

A large number of adult weevils seriously infesting leaves of Eurya nitida Korthals, family Theaceae, were found in a mountainous forest of Tam Dao, northern Vietnam. The weevils belong to the genus Adorytomus Voss, which is presently a monotypical genus known from China and Japan (Voss, 1953; Chûjô \& Voss, 1960). No biological information has ever been available on Adorytomus, however a strong and extensive association with the camellia family is becoming clear through the intensive surveys of this plant family (Kojima, unpubl. data). The weevils collected at Tam Dao unexpectedly consisted of three species, of which two are described below. The third species is left as an unnamed species since the materials were not enough in number for description.

This paper is dedicated to Prof. Osamu Tadauchi on the occasion of his retirement from Kyushu University. He generally favors drinking tea, leaves of Camellia, the best known genus of Theaceae and also threatened by infestation of Adorytomus weevils.

Type materials are preserved in the Laboratory of
Entomology, Tokyo University of Agriculture, Atsugi.

\section{Genus Adorytomus Voss}

Adorytomus Voss, 1953, 78 (type-species: Adorytomus anoploides Voss, 1953; China: Fukien; Erirhininae: Dorytomini); Voss, 1958, 114 (Notarinae: Notarini: Dorytomina); Chûjô \& Voss, 1960, 10 (Japan); Morimoto, 1989, 508 (Tychiinae: Endaeini); AlonsoZarazaga \& Lyal, 1999, 78 (Curculioninae: Ellescini: Dorytomina).

Voss (1953) described as "Krallen frei, ungezähnt", however, the claws are toothed at the base, and each claw is provided with a broad flat tooth. The lateral margins of elytra are more or less abruptly, arcuately produced laterally at the overlapping point of the apex of metepisternum and filled with setae internally in both sexes (Figs. 9-11). This is a unique feature so far unknown among weevils, and the function is uncertain.

Systematic placement of this genus follows the recent catalogue (Alonso-Zarazaga \& Lyal, 1999). Many undescribed species from Japan, Taiwan, China and Malaysia are in the senior author's collection. Systematic revision with their phylogeny, biogeography and weevil-host interrelations will be undertaken in the future.

Distribution. Japan, China, Vietnam. New to Vietnam. Remarks. Voss (1953) compared Adorytomus with

E-mail: h3kojima@nodai.ac.jp 
Neomycta Pascoe, 1877, now classified in the incertae sedis of Curculioninae (Alonso-Zarazaga \& Lyal, 1999), occurring in New Zealand. Although he commented that they can be distinguished by the structure of their claws, it is based on a misobservation as mentioned above. They are not only very similar to but are also probably related to each other, but the elytral projection at the overlapping point of the apex of metepisternum is unique to this genus. Further study is required to investigate their relationship.

\section{Adorytomus tadauchii Kojima sp. nov.}

(Figs. 1-4, 9, 12-16)

Male. Length: 1.9-2.2 mm; width: 1.0-1.2 mm.

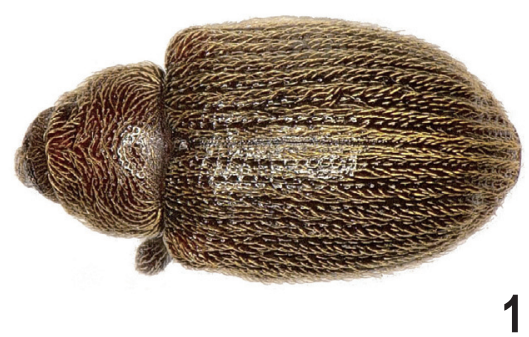

1

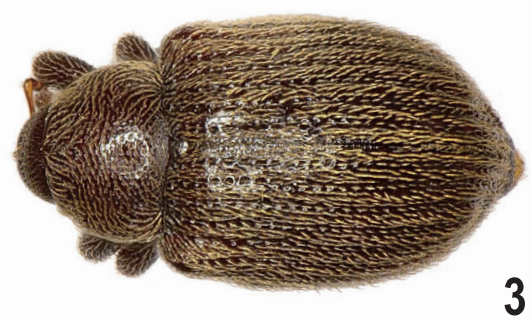

3

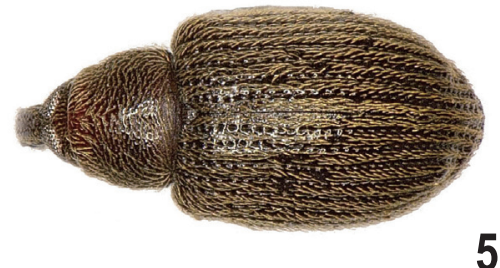

5

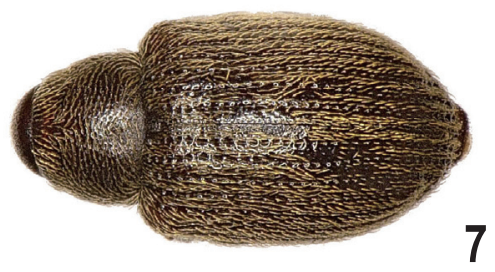

Derm dark reddish brown, antennae, tibiae and tarsi reddish brown, underside, often elytra dark brown to blackish; clothed with pale setae.

Head with frons between eyes very narrow, with two rows of setae. Eyes large in lateral and frontal views. Rostrum slightly longer than pronotum, dorsal margin slightly concave at base and continuous with head, weakly curved on dorsum and more weakly so on venter in lateral view; dorsum with weak carina on each side behind antennal insertion. Antennae inserted at apical third of rostrum; scape a little shorter than funicle; funicle with 1 st segment about twice as long as broad, 2nd 2/5 times as long as $1 \mathrm{st}$, 3 rd to 7 th subequal in length, a little shorter than $2 \mathrm{nd}$, 7th twice as broad as long; club as long as about basal five

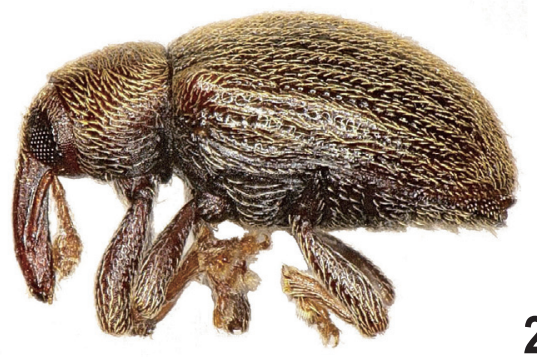

2
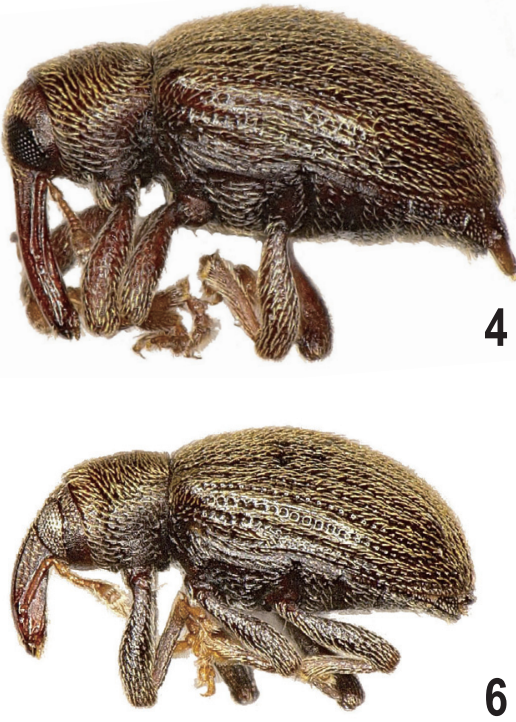

6

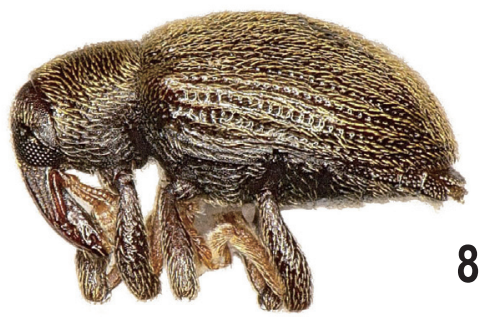

Figs. 1-8. Habitus photographs of the Vietnamese Adorytomus spp. (1-4, A. tadauchii sp. nov. ; 5-6, A. yukikoae sp. nov.). - 1, 2, 5, 6, male; 3, 4, 7, 8, female. 
segments of funicle combined.

Prothorax 1.4 times as wide as long, widest at basal third. Elytra 1.3-1.4 times as long as wide, widest at middle; intervals each with three rows of setae except $1 \mathrm{st}$ intervals with four rows of setae, median row of setae longer. Legs with femora minutely dentate.

Prosternum with coxae narrowly separated. Mesosternal process nearly as wide as middle coxa. Basal two ventrites slightly flattened in middle.

Terminalia as illustrated (Figs. 12-14); sternite 8 unpaired, spiculum gastrale asymmetrical; tegmen with pair of paramere; aedeagus with orificial sclerite developed to lobe on each side; internal sac distinctly spiculate around gonopore and finely so in median part.

Female. Resembles male except rostrum about 1.2 times as long as pronotum; antennae inserted a little beyond middle, funicle with 1 st segment about thrice as long as broad and venter with basal two ventrites inflated. Terminalia as illustrated (Figs. 15, 16); sternite 8 with apodeme relatively short and broadened at base; spermatheca J-shaped.

Type series. Holotype: male. Mt. Mo Qua (N21 $27^{\prime} /$ E105³8'; alt. 980 1025m), Tam Dao, Vinh Phuc Prov., Vietnam, 31-V-2011, Hiroaki Kojima. Paratypes. 65 males and 50 females, same data as the holotype.

Distribution. N. Vietnam (Vinh Phuc Prov.).

Etymology. Named after Prof. Osamu Tadauchi in commemoration of his retirement from Kyushu University and his great achievement in the taxonomy of Hymenoptera.

Biology. Weevils were abundant on and seriously infesting leaves of Eurya nitida (Figs. 22, 23).

Remarks. This species is easily separable from A. anoploides Voss by the dark reddish brown coloration (black or reddish brown in A. anoploides) and the approached eyes so that the frons is very narrow (eyes distant about half width of base of rostrum in A. anoploides).

\section{Adorytomus yukikoae Kojima sp. nov.}

(Figs. 5-8, 10, 17-21)

Male and Female. Length: 1.6-1.9 mm (male) and 2.0 $\mathrm{mm}$ (female); width: 0.9-1.0 $\mathrm{mm}$ (male) and $1.0 \mathrm{~mm}$ (female).

Very similar to A. tadauchii, but rostrum shorter than pronotum in both sexes, with indefinite sexual dimorphism, dorsal margin continuous with head in arc; prothorax 1.3-1.4 times as wide as long; elytra 1.4 times as long as wide.

Terminalia as illustrated (Figs. 17-21); aedeagus subtrapezoidal at apex; internal sac densely and finely spiculate in middle. Spermatheca J-shaped.

Type series. Holotype: male. Mt. Mo Qua (N2127'/ E105³8'; alt. 980 1025m), Tam Dao, Vinh Phuc Prov., Vietnam, 31-V-2011, Hiroaki Kojima. Paratypes. 1 male and 4 females, same data as the holotype.

Distribution. N. Vietnam (Vinh Phuc Prov.).

Etymology. Named after the wife of Prof. Osamu Tadauchi, Prof. Yukiko Tadauchi, who has consistently supported him.

Biology. Weevils might be collected on the same tree, Eurya nitida, mixed with a number of the aforementioned species and also the next species though it was not possible to distinguish them in the field.

Remarks. This species was detected after close examination under the microscope of the aforementioned species collected from the same locality. This weevil is slightly smaller than the preceding species, and the slight
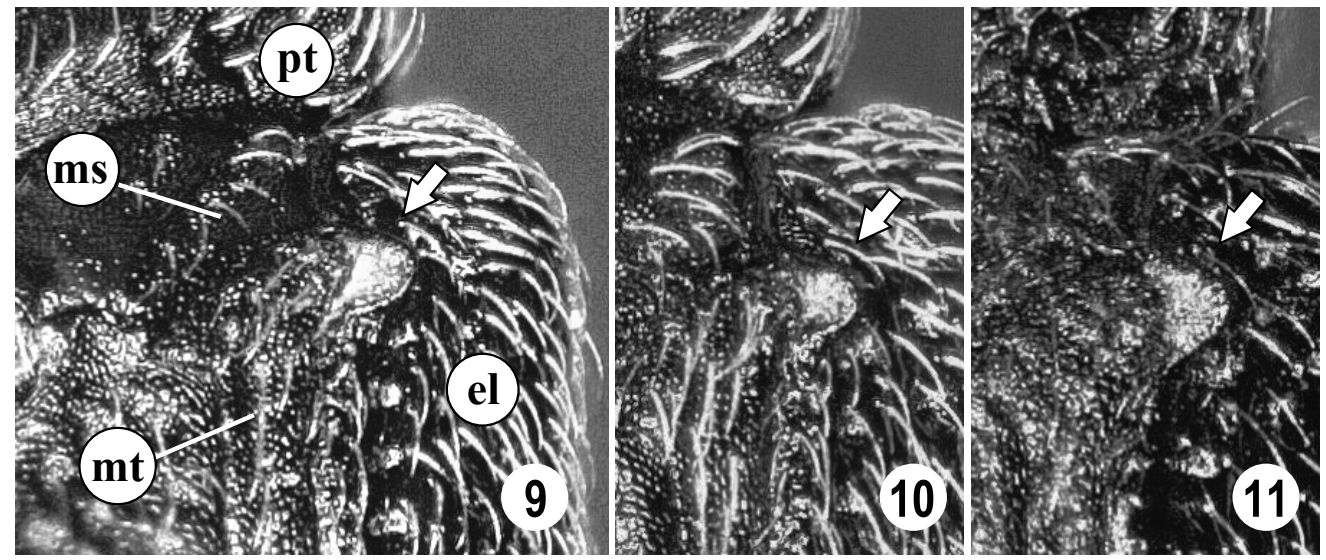

Figs. 9-11. Photographs of pro- to metathoraces of the Vietnamese Adorytomus, latero-ventral view (arrow indicates elytral projection). - 9, A. tadauchii sp. nov.; 10, A. yukikoae sp. nov.; 11, A. sp. 1. Abbreviations: $\mathrm{pt}=$ prothorax; $\mathrm{el}=$ elytra; $\mathrm{ms}=$ mesepimeron; $\mathrm{mt}=$ metepisternum. 
sexual dimorphism of the rostrum is unique to this species among its congeners.

\section{Adorytomus sp. 1}

(Fig. 11)

Specimens examined. 3 exs., Mt. Mo Qua (N21 $27^{\prime} /$
E105³8'; alt. 980 1025m), Tam Dao, Vinh Phuc Prov., Vietnam, 31-V-2011, Hiroaki Kojima.

Remarks. This species differs from the preceding two species in the black coloration and the separated eyes, and is very similar to A. anoploides Voss. Further materials are required for comparison.
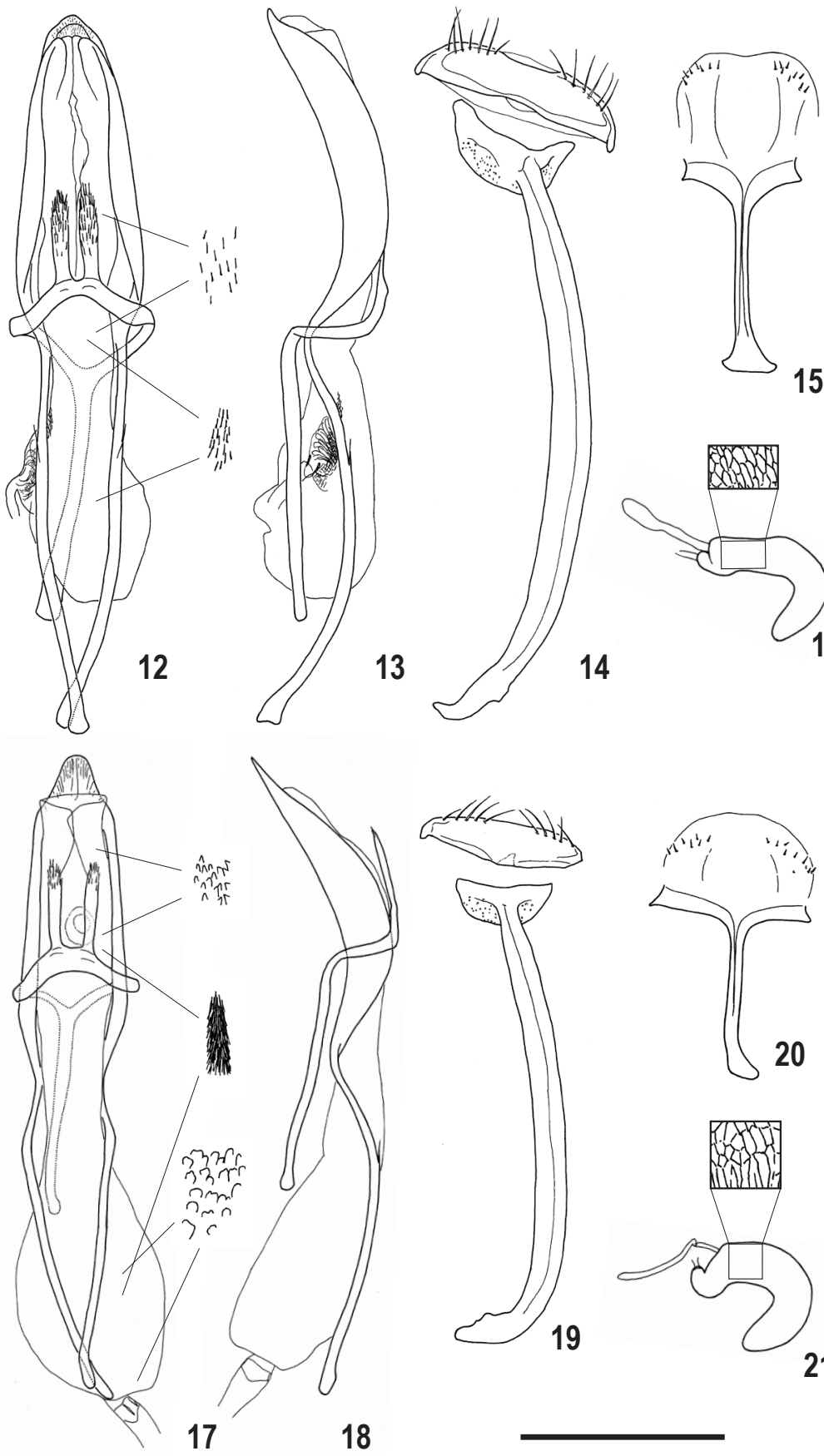

20

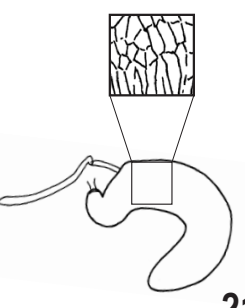

\section{1}

Figs. 12-21. Male and female terminalia of the Vietnamese Adorytomus spp. (12-16, A. tadauchii sp. nov.; 17-20, A. yukikoae sp. nov.). - 12, 17, aedeagus and tegmen, dorsal; 13, 18, ditto, lateral; 14, 19, male sternite 8 and spiculum gastrale, ventral; 15,20 , female sternite 8 , ventral; 16,21 , spermatheca. 

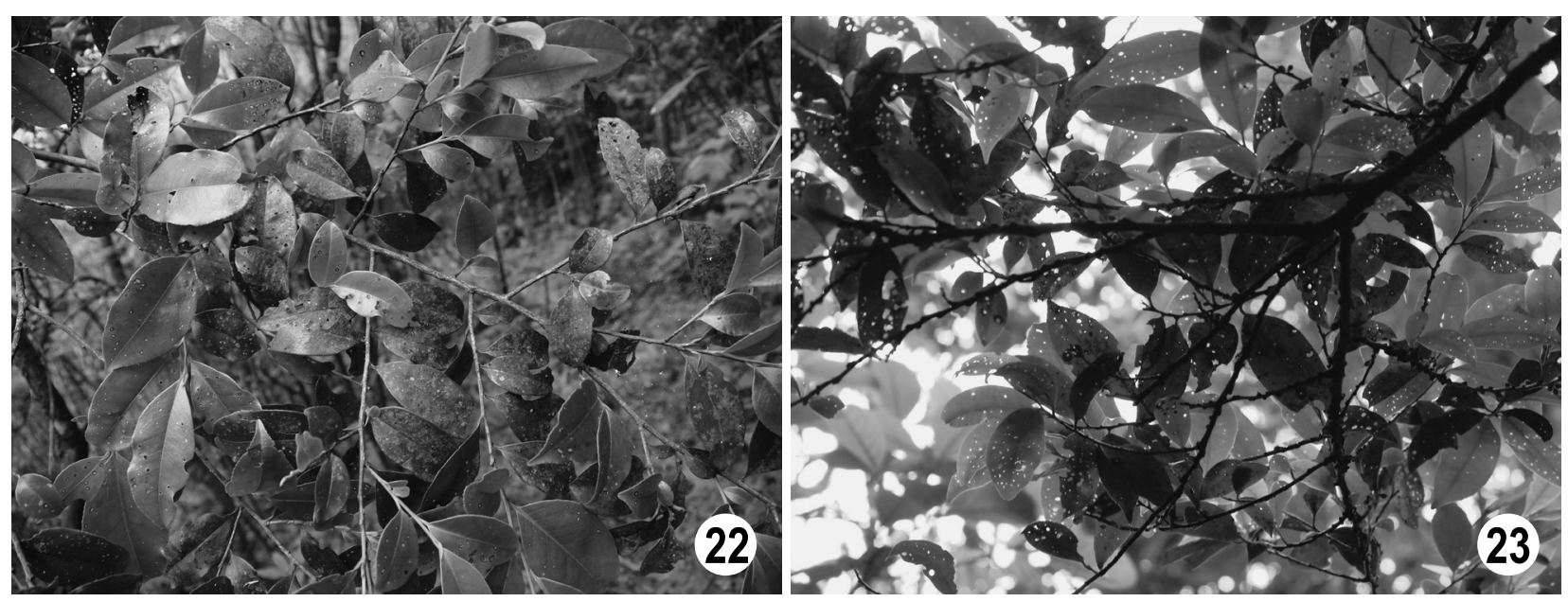

Figs. 22, 23. Photographs of Eurya nitida, on which adult Adorytomus spp. were collected (Mt. Mo Qua, Tam Dao). -22, Dorsal aspect; 23, ventral aspect (many small plots contain feeding traces from adult Adorytomus spp.).

\section{Acknowledgements}

The authors thank Dr. K. Morimoto for his review of the manuscript, Dr. M. Schmitt (Zoologisches Forschungsmuseum Alexander Koenig, Bonn) for his kind help accessing the collection, Dr. Ths. Nguyen The Cuong (Department of Botany, Institute of Ecology and Biological Resources, Hanoi) for his identification of Eurya plant, and Mr. Nguyen Duc Long (Tam Dao National Park) for making arrangements for our survey. We also thank two anonymous referees for their useful comments. This study is supported in part by KAKENHI (21405019; head investigator: S. Okajima).

\section{References}

Alonso-Zarazaga, M. A. \& C. H. C. Lyal, 1999. A World Catalogue of Families and Genera of Curculionoidea
(Insecta: Coleoptera). 315 pp. Entomoplaxis S. C. P., Barcelona.

Chûjô. M. \& E. Voss, 1960. Neue Curculioniden-Subfamilie, -Gattungen und -Arten von Japan (Coleoptera, Curculionidae). Mem. Fac. Liberal Arts \& Educ., Kagawa Univ., 94 (2): 1-17.

Morimoto, K., 1989. Curculionidae. In: Hirashima, Y. (supervised). A Check List of Japanese Insects. 1: 498-525. Entomological Laboratory, Faculty of Agriculture, Kyushu University and Japan Wild Life Research Center, Fukuoka.

Min, T-1. \& B. Bartholomew, 2007. Theaceae. In: Wu, Z. Y., P. H. Ravan \& D. Y. Hong (eds.). Flora of China, Vol. 12: 366478. Science Press, Beijing and Missouri Botanical Garden Press, St. Louis.

Voss, E., 1953. Über einige in Fukien (China) gesammelte Rüßler, IV. (Col., Curc.). Entomol. Blätter, 49: 42-82.

Voss, E., 1958. Ein Beitrag zur Kenntnis der Curculioniden in Grenzgebiet der Orientalischen zur Paläarktischen Region (Col., Curc.). Decheniana, Beiheft 5: 1-139. 